\title{
Insulodrilus martensi, a new species of Phreodrilidae (Oligochaeta) from Lake Tanganyika (East-Africa)
}

\author{
P. Martin1 \\ N. Giani2
}

Keywords : aquatic oligochaetes, Phreodrilidae, Insulodrilus martensi, Africa.

Insulodrilus martensi sp. $\mathrm{n}$. is the third species of the genus Insulodrilus reported from Lake Tanganyika (East Africa). A description of the new species is given below and a comparison with its congeners occurring in the same lake is made. From this comparison, the placement of Insulodrilus tanganyikae (Brinkhurst 1970) to the genus Insulodrilus is queried. The creation of a new genus might resolve its ambiguous position, straddling the genera Astacopsidrilus and Insulodrilus.

Insulodrilus martensi, une nouvelle espèce de Phreodrilidae (Oligochaeta) du lac Tanganyika (Afrique de l'Est)

Mots clés : oligochètes aquatiques, Phreodrilidae, Insulodrilus martensi, Afrique.

Insulodrilus martensi n. sp. est la troisième espèce du genre Insulodrilus signalée dans le lac Tanganyika (Afrique de l'Est). Une description de la nouvelle espèce est donnée ci-après et une comparaison est faite avec ses congénères en provenance du même lac. Il résulte de cette dernière que l'appartenance d'Insulodrilus tanganyikae (Brinkhurst 1970) au genre Insulodrilus est mise en doute. La création d'un nouveau genre pourrait résoudre sa position ambiguë, à cheval entre les genres Astacopsidrilus et Insulodrilus.

\section{Introduction}

The Phreodrilidae is a small family of freshwater Oligochaeta including 6 genera and 28 species (Brinkhurst 1991). The genus, Insulodrilus Brinkhurst, 1991 involves the greatest diversity, with 10 species reported so far. While being mainly confined in the Antipodes ( 8 species mentioned from New Zealand, Tasmania and Campbell Island), the genus is also known from Argentina (South America), Lake Tanganyika (East Africa) and an unidentified species has even been found in the surroundings of Lake Titicaca (South America) (Giani et al. 1995).

\footnotetext{
1. Institut royal des Sciences naturelles de Belgique (I.R.Sc.N.B.), Section Biologie des Eaux Douces (Royal Belgian Institute of Natural Sciences, Freshwater Biology), 29, rue Vautier, B-1040 Brussels, Belgium.

2. Université Paul Sabatier, Laboratoire d'Hydrobiologie, URA CNRS 695, 118, route de Narbonne, 31062 Toulouse Cedex, France.
}

Thus far, two Insulodrilus species were reported from Lake Tanganyika, namely $I$. tanganyikae (Brinkhurst 1970) and the recently described $I$. genitalisetifera Martin \& Brinkhurst 1994. Insulodrilus martensi sp. $\mathrm{n}$. is the third species of the genus mentioned from the lake.

\section{Material and Methods}

The material of Insulodrilus martensi sp. n. was sampled by Dr. K. Martens (I.R.Sc.N.B.). A total of 29 samples were taken from eight localities inshore the littoral of Burundi in 1991, with a petite Ponar grab and with a dredge (Fig. 1). One station (LT/91/27 at Gitaza Bay, Burundi ; $3^{\circ} 36^{\prime} 16^{\prime}$ 'S, $29^{\circ} 19^{\prime} 46^{\prime}$ 'E, Fig. 1A) was sempled again in 1992 with the same Ponar grab.

The new species was found in 6 samples only. All material was fixed in $10 \%$ formalin and later preserved in $70 \%$ alcohol. Specimens were either mounted in polyvinyl lactophenol for examination 
of setae (paratypes 92.287.1, 92.294.1, 92.294.2, 92.296.1, 92.028.1), or stained in alcoholic carmin and mounted in canada balsam after dissection (holotype 93.092.1 and paratype 93.092.2). Drawings were made by means of a camera lucida. The type series are deposited in the "Institut Royal des Sciences Naturelles de Belgique " (I.R.Sc.N.B. ; Bruxelles) under $\mathrm{N}^{\circ}$ I.G. 27828 and 27924.

\section{Insulodrilus martensi, sp. n. (Fig. 2A-E)}

Holotype : 93.092.1, a dissected sexually mature specimen.

Type Locality : Lake Tanganyika, Bay opposite Karonda village (4'5'86'S, 29 $28^{\circ}$ '58' 'E ; Fig. 1E), 3 m (26 september 1991), petite Ponar grab.

Paratypes : 4 specimens from type locality (slides 92.294.2, 93.092.2, two in alcohol) ; 4 specimens from the delta of River Mushara, near Banda village $\left(4^{\circ} 26^{\prime} 18^{\prime \prime} \mathrm{S}, 2^{\circ} 39^{\prime} 27^{\prime} ' \mathrm{E}\right.$, Fig. $1 \mathrm{H}$; slide 92.287.1, three in alcohol) ; 2 specimens from Cap Mvugo (4'17'31''S, 29०33'27''E, Fig. 1G ; slide 92.296.1, one in alcohol); 5 in front of the delta

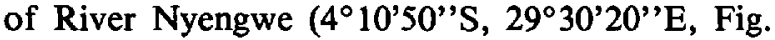
$1 \mathrm{~F}$; in alcohol) ; 6 from the bay in front of a vil-

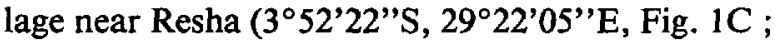
slide 92.294.1, 5 in alcohol) ; 1 from the bay in front of Gitaza (336'16' 'S, 29 $19^{\circ} 46^{\prime}$ 'E, Fig. 1A ; slide 93.028.1).

Etymology : The species is named after Dr. Koen Martens, a colleague of the senior author at the I.R.Sc.N.B., whose dynamism is a precious help, and as a mark of gratitude for all the personal enrichment that this author owes him.

Description : Length of holotype $7.9 \mathrm{~mm}$ (10.2 mm, paratype 92.294.2), breadth at widest segment (XIV, slightly squeezed) $0.62 \mathrm{~mm}, 51$ segments (48-56, paratypes 92.294.2, 93.092.2).

Two ventral setae per bundle, sigmoid with a slight nodulus. Upper tooth of similar length or slightly shorter than lower tooth (Fig. 2E). Size and shape of the ventral setae in 'each bundle similar along the entire body. Replacement setae sometimes present (four ventral setae therefore visible). Ventral setae XIII replaced by modified spermathecal setae (Fig. 2B, C sps). Two modified setae per bundle, thin, elongate, grooved ectal to the nodulus, slightly dissimilar in size and set close together. Tip of the longest spermathecal seta closed and syringe needle-like. Tip of the smallest seta showing all intermediates between clearly bidentate and closed ; most often, slightly bidentate, pen nib-like tip (Fig. 2C, see arrow). No ventral setae on XII.

Dorsal setae from III, (1) 2 hair flanked by (2) 4 " support " setae which are not extending beyond the body wall (Fig. 2D). Anterior hair setae smaller than posterior ones and suppler, often bent in mountings ; usually two per bundle. Posterior hair setae stiffer (often broken in mountings) and straighter ; frequently one per bundle. Dorsal setae present on XIII.

Male pores on XII, opening ventrally and poste$\operatorname{riad}$ (Fig. 2A, mp). Atria coiled, without lumen (Fig. 2A, a). Pendant penes, tubular in half of their lower part, wider in the upper half (Fig. 2A, $p$ ). Surface of penis with an alveolate relief, slightly rough in the upper part due to small (chitinous ?) grains sometimes absent. No cuticular penis sheaths. Penis in a muscular cavity, its basis fixed with a muscular connection to the body wall dorso-laterally. Sperm funnels opening in XI, giving rise to very coiled vasa deferentia in the lower anterior corner of the segment ; straighter posteriad (Fig. 2A, $s f$, $v d$ ). Vasa deferentia thin, opening into the base of atria near union with penis. Ovary near union with atrium, vas deferens and penis (Fig. 2A,o).

Spermathecal pores ventrally on XIII (Fig. 2B, $s p)$. Long spermathecal ducts with narrow lumina leading to short muscular vestibulae (Fig. 2B, v), lying on the floor of XIII, without muscular fixation to the roof of body wall and opening onto the ventral surface by a fold in body wall. Voluminous ampullae (Fig. 2B), nearly filling the coelom on (XVI) XVII and (XVII)XVIII, and full of material showing a certain organization (sperm bundles ; Fig. $2 \mathrm{~B}, s b$ ). Short circular: clitellum on XIII. Sperm sacs in VIII-XI and XIV-XV, egg sacs in XIV.

Remarks: The presence of support setae in the dorsal bundles, the pendant penes and the ventral spermathecal pores possessing vestibulae not involving the female funnels are characteristics of the genus Insulodrilus (Brinkhurst 1991). I. martensi sp. $\mathrm{n}$. is very close to the recently described $I$. genitalisetifera Martin \& Brinkhurst, 1994, from lake Tanganyika. The reproductive system is almost similar, the only obvious difference being the spermathecal ampullae of $I$. martensi sp. n. rejected back to XVIIXVIII instead of XV-XVI for $I$. genitalisetifera, resulting in different lengths in spermathecal ducts. 


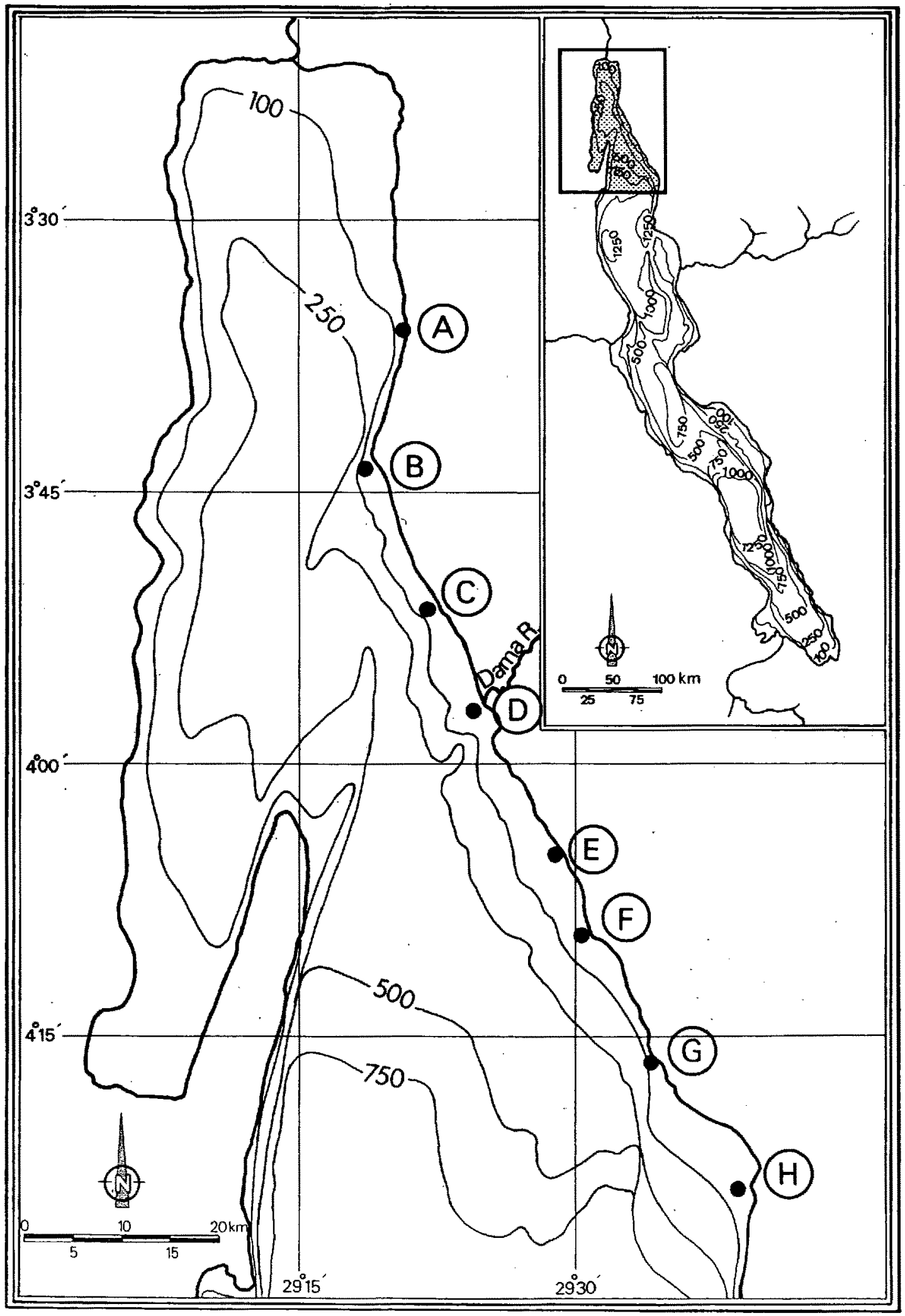

Fig. 1. Map showing the location of the stations sampled in Lake Tanganyika and the stations where the new species was found $(A, C, E, F, G, H)$. Isobaths in metres.

Fig. 1. Localisation des sites de prélèvements dans le lac Tanganyika et des stations $(A, C, E, F, G, H)$ où la nouvelle espèce a été récoltée. Isobathes en mètres. 


\section{Abbreviations used in Fig. 2 :}

$a$ : atrium, $d s:$ dorsal setae, $f p$ : female pore, $m:$ muscles, $m p:$ male pore, $o:$ ovary, $p:$ penis, $s:$ septum, $s b:$ sperm bundles, $s f:$ sperm funnel, spd : spermathecal duct, spp : spermathecal pore, sps : spermathecal setae, $s p z:$ spermatozoa, $v:$ vestibule, $v d:$ vas deferens, $v s:$ ventral setae.

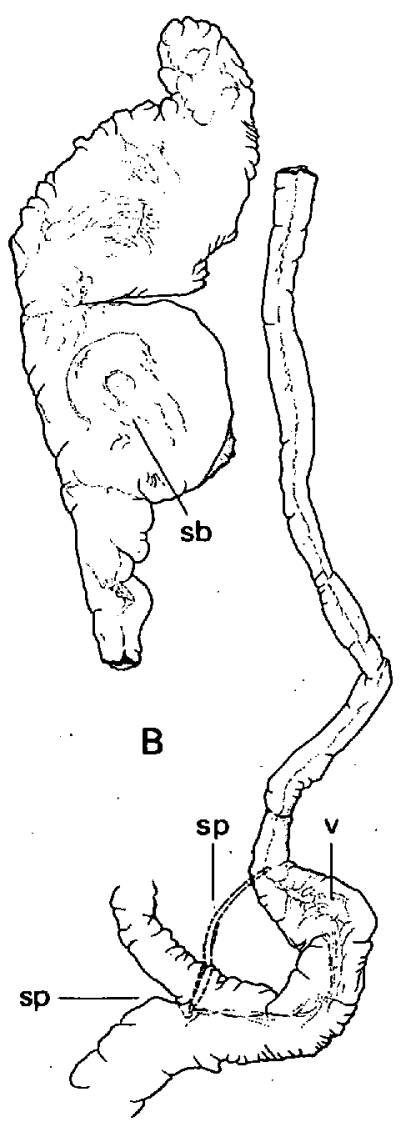

A
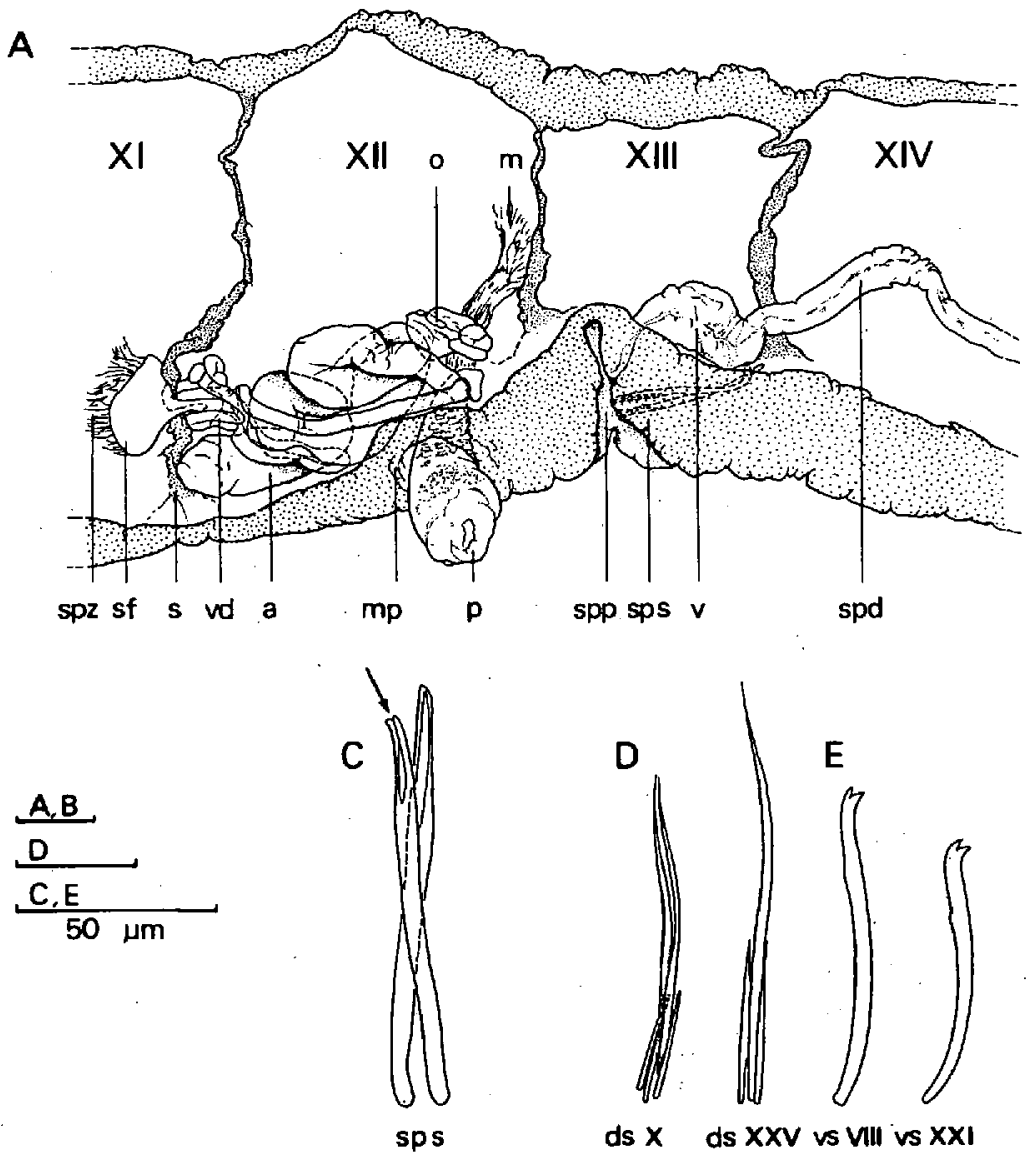

Fig. 2. Insulodrilus martensi sp. n. A : genital organs in segments XI-XIV. B : spermatheca (left side). C : spermathecal setae, segment XIII. D : dorsal hair setae with support setae. E : ventral setae. A-B : holotype 93.092.1. C-E : paratype 93.028 .1$.

Fig. 2. Insulodrilus martensi n. sp. A : appareil génital dans les segments XI-XIV. B : spermathèque (côté gauche). C : soie spermathécale sur le segment XIII. D : soie capillaire dorsale et ses soies d'accompagnement. E : soie ventrale. A-B : holotype 93.092.1. C-E : paratype 93.028.1.

Externally, these species differ from each other by the modified genital setae on XII present in $I$. genitalisetifera but absent in $I$. martensi sp. $\mathrm{n}$. I. martensi sp. $\mathrm{n}$. has dorsal setae present on XIII, support setae always present and (1)2 setae per bundle. On the contrary, $I$. genitalisetifera has no dorsal setae on XIII, no support setae from XXVII and (2)3(4) setae per bundle. Moreover, dorsal setae of the latter species become shorter and stouter from $\mathrm{XXV}$, giving a spiny impression for the posterior segments (Martin \& Brinkhurst 1994).

I. martensi sp. $\mathrm{n}$. has no striking character which could define it unequivocally, except for an alveolate penis. Such a penis is shared with $I$. genitalisetifera but in the latter case, there are genital setae. 
An alveolate penis has never been mentioned for other Insulodrilus species, but this possibility cannot be dismissed because this organ has often been poorly described. Be that as it may, other Insulodrilus species can easily be distinguished from $I$. martensi sp. $\mathbf{n}$. by the assessment of the following characters : dorsal or ventral setae, modified spermathecal setae and cuticular penis sheath.

Six species possess modified spermathecal setae (excluding $I$. genitalisetifera and $I$. martensi). The presence of cuticular penis sheaths isolates $I$. tanganyikae (Brinkhurst 1970) from them. Amongst the other five species, three have characteristic dorsal setae, as suggested by their specific name. I. nudus Brinkhurst and Fulton (1979) has broad-based dorsal setae, narrowing abruptly, nonserrate ; $I$. magnaseta Brinkhurst and Fulton (1979) and I. plumaseta Brinkhurst and Fulton (1979) have brush-tipped dorsals. Finally, the last two species I. litoralis Michaelsen (1924) and I. lacustris Benham $(1903,1904)$ have two dissimilar ventral setae per bundle, one bifid and one simple-pointed.

Distribution and habitat : To date only known from Lake Tanganyika. 3-50 m, sand and silty sand.

\section{Discussion}

Ancient lakes are well known to be the centre of an intense intralacustrine speciation resulting in groups of closely related, endemic species (Martens et al. 1994). The oldest Lake Baikal (20-25 Ma ; Martin 1994) harbours more than 152 species of oligochaetes, 111 of them being endemic (Martin 1995). On the contrary, the oligochaete fauna of the hardly younger Lake Tanganyika (20 Ma ; Coulter 1994) is very scarce, due mainly to an obvious lack of studies (Martin 1995). Only 9 species (7 endemics) have been reported in Lake Tanganyika to date, amongst them two Insulodrilus species, namely $I$. tanganyikae and I. genitalisetifera (Martin \& Brinkhurst 1994). Insulodrilus martensi sp. $n$. is the third member of the genus reported from the lake.

Within the Insulodrilus genus, I. martensi and I. genitalisetifera are closer than any other species, suggesting a recent common ancestor. On the other hand, I. tanganyikae is problematic, not only in comparison with the other two Tanganyikian Insulodrilus but also with other representatives of the genus.
I. tanganyikae has a very distinctive reproductive system : (1) the vasa deferentia open into the basis of atria at some distance from union with penes, (2) the penes possess a cuticular sheath and (3) the large spermathecal vestibulae are attached dorsally by a thick muscular layer. The last two characters are unique for this species in the Insulodrilus group so far. No other Insulodrilus species have a penis sheath and their vestibulae are typically small, swelling on the end of the ducts and essentially ventral. Similar vestibulae, running right to the dorsal wall of the body, with muscular attachment, can be found in some Astacopsidrilus, but the female openings are involved with the vestibulae (Brinkhurst, in litt.).

These two unique characters could be considered as sufficiently important to query the belonging of I. tanganyikae in the genus Insulodrilus. However, the situation is becoming more confuse following a study of new material, and new species, from Australia so that the line between Insulodrilus and Astacopsidrilus is blurring (Pinder in litt.). Accordingly, it would be more judicious to hold off on the creation of a new genus for tanganyikae for the moment, and to wait for the analysis of this new material. Moreover, a study of new material (and probably new species) from Lake Tanganyika is badly needed.

\section{Acknowledgements}

\begin{abstract}
We are indebted to Dr. Koen Martens who sampled Lake Tanganyika and allowed us to study the material, to Dr. Rudy Jocqué (Musée Royal d'Afrique Centrale, Belgium) for the lending of the type material of Phreodrilus (Astacopsidrilus) tanganyikae Brinkhurst, 1970, to Marcel Cartois for technical assistance and to Claudine Devries-Duchène who kindly made a neat copy of the figures. Dr. R. O. Brinkhurst and A. Pinder are greatly acknowledged for their constructive comments.
\end{abstract}

\section{References}

Benham W.B. 1903. - On some new Species of Aquatic Oligochaeta from New Zealand. Proc. Zool. Soc. London, 2 : 202-232.

Benham W.B. 1904. - On some New Species of the Genus Phreodrilus. Q. Jl. Microsc. Sci., $48: 271-298$.

Brinkhurst R.O. 1970. - A further contribution towards a study of the aquatic Oligochaeta of Africa. Rev. Zool. Bot. Afr., 81 : 101-108.

Brinkhurst R.O. 1991. - A. phylogenetic analysis of the Phreodrilidae (Annelida, Oligochaeta), with a description of a new species. Can. J. Zool., $69:$ 2031-2040.

Brinkhurst R.O. \& Fulton W. 1979. - Some aquatic Oligochaeta from Tasmania. Rec. Queen Vic. Mus., 64 : 1-8. 
Coulter G. 1994. - Lake Tanganyika. In : K. Martens, B. Goddeeris \& G. Coulter (eds), Speciation in Ancient Lakes, Arch. Hydrobiol. Beih. Ergebn. Limnol., 44 : 13-18.

Giani N., Martin P. \& Juget J. 1995. - A new species of Phreodrilidae (Oligochaeta), Astacopsidrilus naceri sp. n., from Morocco (North Africa) with notes on the biogeography of the family. Can. J. Zool, submitted.

Martens K., Coulter G. \& Goddeeris B. 1994. - Speciation in Ancient Lakes - 40 years after Brooks. In : K. Martens, B. Goddeeris \& G. Coulter (eds), Speciation in Ancient Lakes, Arch. Hydrobiol. Beih. Ergebn. Limnol., 44 : 75-96.

Martin P. 1994. - Lake Baikal. In : K. Martens, B. Goddeeris \& G. Coulter (eds), Speciation in Ancient Lakes, Arch. Hydrobiol. Beih. Ergebn. Limnol., 44 : 3-11.
Martin P. 1995 - Oligochaeta and Aphanoneura in ancient lakes : a review. Hydrobiologia, in press.

Martin P. \& Brinkhurst R.O. 1994. - A new species of Insulodrilus (Oligochaeta, Phreodrilidae) from Lake Tanganyika (East Africa) with notes on the oligochaete fauna of the lake. Arch. Hydrobiol., $130: 249-256$.

Michaelsen W. 1924. - Papers from Dr. Th. Mortensen's Pacific Expedition 1914-16. XVII. Oligochäten von Neuseeland und den Auckland-Campbell-Inseln, nebst einigen anderen . Pacifischen Formen. Vidensk. Medd. Dansk. natur. Foren., $75: 197-240$. 